\title{
Ahmed Midhat Efendi'nin Ahmet Metin ve Şirzad Romanında İstitrâd Değerlendirmesi ${ }^{*}$
}

\section{Funda Çapan Özdemir*}

\begin{abstract}
0̈z
Ahmet Midhat Efendi, eğitim ve öğretimi roman sanatının temeli hâline getirmiş bir yazardır. Romanda olay akışını birden keserek, o anda geçen bir durum, bir mesele, bir nesne hakkında bilgi verir, sonra tekrar esas konusuna döner. Ahmet Metin ve Şirzad romanı, Ahmet Midhat Efendi'nin istitradı en fazla kullandığ eserdir. Ahmet Metin ve Şirzad romanındaki istitradlar: 1. Müsbet ve insanî bilimlere dair bilgiler, 2. Denizcilik-gemicilik bilgileri, 3. Gidilen görülen yerlere, seyyahı bekleyen durumlara dair bilgiler, 4. Türk-Osmanlı ve İslâm medeniyetinin değerlerine dair bilgiler, 5. Avrupa medeniyetine dair bilgiler, 6. Öğretim-eğitim meselelerine dair bilgiler olarak altı maddede toplanabilir. Ahmet Metin ve Şirzad, yazarın ilk eserini yayınladığı 1870'den bu eseri yayınladığı 1891 tarihine kadar, bilgide ulaştığı son noktayı göstermesi bakımından önemli bir eserdir. Bu metindeki istitradlar, Ahmet Midhat Efendi'nin 1890'larda bir Osmanlı aydınının neler bilmesi gerektiğine dair görüşlerini de açıklamaktadır.
\end{abstract}

\section{Anahtar Kelimeler}

Ahmet Midhat Efendi, aydın, roman, istitrâd, bilgi, öğrenme-öğretme.

\footnotetext{
Geliş Tarihi: 11 Şubat 2014 - Kabul Tarihi: 16 Haziran 2014 Bu makaleyi şu şekilde kaynak gösterebilirsiniz: Çapan Özdemir, Funda (2019). “Ahmed Midhat Efendi’nin Ahmet Metin ve Şirzad Romanında İstitrâd Değerlendirmesi”. bilig - Türk Dünyası Sosyal Bilimler Dergisi 88: 205-226.

** Dr. Öğr. Üyesi., Yozgat Bozok Üniversitesi, Fen-Edebiyat Fakültesi, Türk Dili ve Edebiyatı Bölümü Yozgat/Türkiye ORCID ID: http://orcid.org/0000-0002-3950-4842 funda.capan.ozdemir@bozok.edu.tr
} 


\section{Giriş}

On dokuzuncu yüzyıl, dünya bilim tarihi açısından mühim bir zamandır. Batıda bilim ve tekniğin hızlı bir şekilde gelişmesi ve çeşitli alanlara uygulanması, Avrupa kültürü ve sanatı, Avrupadaki sosyal ve iktisadi hayat, zengin-müreffeh Avrupa ülkeleri ve şehirleri, başta Ahmet Midhat Efendi olmak üzere Tanzimat yazarları tarafından bize örnek gösterilir. Diğer pek çok Tanzimat yazarı gibi Ahmet Midhat Efendi de Osmanlı Devleti'nin gelişmesinin halkın bilgi seviyesinin yükseltilmesi ile mümkün olacağına inanır. Eğitim ve öğretim ile halka hizmeti, romancılı̆̆ının temel düsturu haline getiren ve "Hâce-i Evvel" adıyla da bilinen yazar, Abmet Metin ve Şirzad romanında fen-matematik, tarih, coğrafya, arkeoloji, mitoloji, filoloji, edebiyat, iktisat, felsefe, psikoloji, sosyoloji, antropoloji gibi müsbet ve insanî bilimler, gemicilik ve denizciliğe dair bilgiler, Türk-Osmanlı ve İslâm medeniyetine dair bilgiler, Avrupa medeniyetine dair bilgiler, öğretim-eğitim meselelerine dair bilgiler hakkında okuyucularını aydınlatmayı amaçlar ve romanında sık sık ansiklopedik bilgiler verir.

\section{Edebî Terim Olarak İstitrâd}

Asıl mevzûdan olmayıp, münasebeti gelmişken söylenen söz anlamına gelen istitrâd bir belâgat terimidir. Kovmak, uzaklaştırmak, sürmek anlamındaki tard kökünden türeyen istitrâd kelimesi, konu değiştirmek, asıl konudan uzaklaşmak, bir düşünceden başka bir düşünceye geçmek gibi terimsel manâlar taşır (Durmuş 1989: 401-402).

Bazı belâgat âlimleri, istitrâd teriminin etimolojisinden yola çıkarak, kelimenin "atlı savaşçının düşmanına yenilip kaçtığı izlenimini verdikten sonra tekrar dönerek işini bitirmesi” şeklindeki anlamı arasında ilgi kurmuşlardır. Nitekim istitrâtta da asıl konu devam ederken beklenmedik bir zamanda ve önceden tasarlanmadan bir münasebet düşmesiyle konu dışına çıkılması ve sonra tekrar eski konuya dönülmesi söz konusudur. Bir kısım belâgat âlimleri ise istitrâd terimini avı kovalamak anlamındaki mutârede kelimesiyle ilişkilendirerek bir av peşinde koşuşturan avcının karşısına başka bir av çıkmasıyla onun peşine takılıp kovaladıktan sonra ilk avına dönmesi temsiliyle izah etmişlerdir (Durmuş 1989: 401-402).

Her iki analoji, istitrâdın terim anlamına uygun olsa da birçok belâgat âlimi tarafından istitrâd terimi, hüsn-i tehallus ile karıştırılmıştır. Bunun sebebi, her 
iki türde de bir konudan diğerine geçilmesidir; ancak tehallusta yeni konuya devam edilirken, istitrâtta eski konuya tekrar dönülür. Yeni konudan kısa bir şekilde bahsedilip, konunun bitirilmesi ve bu durumda eski konuya dönüş yapılmaması istitrâd için sakıncalı görülmemiştir. Tehallusta okuyucunun beklediği ve tasarlanmış tedrîcî yani kademeli bir geçiş söz konusu iken istitrâtta ara konuya beklenmedik bir şekilde geçiş yapılır ve bu da iltifat üslûbu tarzında gerçekleşir. Besyûnî, istitrâdın sözü güzelleştirmek, tek düze devam eden konunun monotonluğunu kırarak okuyucunun dikkatini çekmek, zihnini açmak, söze çeşni katarak ilgi ve merak uyandırmak gibi faydaları olduğunu açıklar (Durmuş 1989: 401-402).

İstitrâd; ilâhiyat, tarih ve edebiyat araştırmalarında geçen bir terimdir. Bu terime anlam verilirken, genel olarak Arap kaynaklarına başvurulur: Istitrâd terimine ilk defa adını veren ve onu yorumlayan kişi ünlü Arap şâiri Ebû Temâm olmuştur. Arap edebiyatının en büyük nesir yazarlarından Câhiz'e göre; istitrâd okuyucuyu sıkıp bıktırmamak ve dinlendirmek için uzun konu arasına bir münasebetle anekdot, fikra, haber, hikâye vb. şeyler sokmaktır. Câhiz' in başta el-Beyân ve't-tebyîn olmak üzere eserlerinin çoğu yoğun bir şekilde istitrâdlarla süslenmiştir. Abbas b. Ali es-San'ânîye göre; istitrâd, daha çok lafız güzellikleriyle ilgili olan fesahat türüdür. İbn Yahyâ el-Alevî ise, istitrâdı övgüyle ve yergiyle sınırlandırarak, türü bunlar arasında gerçekleşen geçişler şeklinde yorumlamıştır. İbn Ebül-İsba, Ebû Hilâl el-Askerî ve Zemahşerî gibi belâgat âlimleri, Kur'ân-1 Kerim'den bazı istitrâd örnekleri vermişlerdir (Durmuş 1989: 401-402).

İstitrâdda asıl amaç; anlatıma değişiklik katmak, dikkat çekmek ve anlatımı zenginleştirmektir. Bu amacın yanı sıra yeni bir türe, özellikle sanatçının otobiyografisine ya da başka bir anısına geçiş maksadıyla kullanıldıkları da görülür. Bu yolla, konunun tek düze anlatımı kırılarak konudan konuya geçiş ve anlatılan konuların daha ilginç olması sağlanır. Tarih, coğrafya, şehir monografisi, biyografi, otobiyografi ve benzeri türlerin edebî eserlerde iç içe geçmiş şekilde işlenmesi; esere belirli bir biçim vermesinin yanı sıra bir üslûp özelliğidir. Aynı zamanda, konuyu bilgilendirmektir. Bu konuların eserdeki veriliş sıraları, genellikle bir plan dâhilinde yapılır. Bu yolla, eserde bir iç düzen ve bir iç akış sağlanır (Mengi 2008: 281-291).

İstitrâd, Osmanlı nesrinin önemli bir üslûp özelliğidir. Metnin dokusuna konuyla bağlantılı olmayan ara söz katma, Osmanlı nesrinde başta şuarâ 
tezkirelerinde olmak üzere genellikle görülür. 17. yy. nesrinde, özellikle Evliyâ Çelebi'nin Seyahatnâme adlı ünlü eserinde, pek çok istitrâd örneği mevcuttur. Eski Türk nesrinin bilinen mensur türleri olan, "menâkıbnâmeler, sergüzeştnâmeler, ta’rifâtlar" ve manzum tür olarak görülen "şehrengîzler" gibi değişik türlerdeki metinlerde yer alan konu gereği bilgilendirme, Evliyâ Çelebi'nin Seyahatnâmésinde sıkça görülür.

Muallim Naci'nin edebî terimleri konu alan, Istılahat-ı Edebiyye adlı çalışmasında, istitrâd terimi, haşv başlı̆̆ı altında ele alınmıştır (Muallim Naci 1984: 27-38). Anlamı itibariyle istitrâd terimiyle yakınlığı bulunan haşv, esas fikre göre fazla görünen söz veya sözlerden ibarettir. Haşv edebî terimi, esasen iki çeşittir: 1. Haşv-i müfsit. 2. Haşv-1 gayr-i müfsit.

Haşv-1 müfsit, anlatılmak istenen fikri bozan haşvdır. Bu gruba giren sözler, metinde yalnız kalabalık etmekle kalmayıp, esas manâyı da anlaşılmaz bir hâle getirirler. Haşv-1 müfsit, üstadların eserlerinde pek nadir bulunur; çünkü söz arasında haşv-1 müfsid söylemek, konuşanın hangi fikri savunduğunu bilmediğine hükmettirebilecek, büyük bir eksikliktir. Haşv-1 müfsidi eserlerinde kullanan büyük şahsiyetlerin bile, insanın acizliğinin belgesi olan tesirlerden kurtulamadıkları düşünülür. Nef'ı’nnin, Nasuh Paşa Mektubu adındaki kasidesinin matlaı olan:

Ne nâmedir bu ki hüsn-i beyân-1 ünvânı

Eder küşâde dil ü tab'-1 müstemendânı

beytinde geçen ünvânı sözü haşv-1 müfsit olabilir; çünkü şâirin maksadı, mektubun tamamını övmek olduğu hâlde, "hüsn-i beyân"ın "ünvân"a verilmesi mektubun, diğer taraflarının anlatımdaki güzelliklerden uzak olduğunu düşündürür. Bir sonraki beyitte geçen,

Ne nâmedir bu ki keyf-i rahîk-i mazmûnı

Verir mülâhazaya bir neşât-1 rûhânî

denilerek durum, açıklanıyorsa da, bir kere haşv-1 müfsit olan söz, o korkuyu akla getirmiştir. Özetleyecek olursak; şair, "ne nâmedir bu ki hüsn-i beyân" diyecekken, vezin ve kafiye zaruretiyle "ne nâmedir bu ki hüsn-i beyân-1 ünvânı” demeye lüzum görmüştür. Bunu anlayabilmek için Nef'înnin şiir üslûbunu bilmek, zarûrîdir. 
Haşv-1 gayr-i müfsit, üç çeşittir: 1. Haşv-1 kabîh. 2. Haşv-1 melîh. 3. Haşv-1 mutavassıt. Haşv-1 kabîh, metinde fazlalığı dikkat çektiğinden söze çirkinlik verir. Haşvın bu çeşidinin güzel olduğunu düşünen, eski ediplerimizin eserlerinde, haşv-1 kabîh çeşitlerine sıklıkla rastlamak mümkündür. Muallim Naci, Türk edebiyatından örneklerle haşv kelimesinin anlamını pekiştirir: Okçuzâde Münşéatíndan "Bu fakîr cânının hasm-1 cânı olup bî-sebep (ü illet) nâvek-i azl ü ihânete âmâc ü esbâb-1 âsâyiş (ü râhat) $1 \mathrm{~m} 1$ târâc eyledi." ve Âkif Paşa Tabsırası'ndan "Yok eğer elçi beyin emriyle ise nasıl lisandır? Biz de bunun tarziyesini isteriz gibi dirice sözlerle bayağı elçi ve tercümânı suçlandırmak mümkün iken merâm (u maksûd) başka olduğundan..." gibi misallere yer verir (Muallim Naci 1984: 27-38).

Türk tarihçisi ve müderrisi Hoca Sadettin Efendi'nin (1536-1599) TacütTevârih adlı eserinde geçen "Sâki-yi tig-i âb-dâr ile bizzat nice diyü sîrete hâdimü'z-zât hamîmim içürdüler." ifadesinden sonra "ve nice düşmen-i zişt-ehrimen ser-şetta tîg-i bî-diriglerinden geçirdiler" cümlesi, haşv-1 kabîh sayılır; çünkü iki ifade arasında anlam yönünden fark yoktur. Fuzûlînnin meşhûr Şikâyetnâmesìndeki "Müddet-i tarassud münkazî olmak" (bekleme müddetinin sona ermesi) ile "eyyâm-1 intizâr serencâm bulmak" (bekleme günlerinin son bulması) ifadeleri, anlam bakımından aynı olup, metinde fazlalık teşkil ettikleri için haşv-1 kabîh sayılırlar (Muallim Naci 1984: 27-38). Haşv-1 melîh, söze güzellik veren haşvdır. Şeyh Gâlib’ in "Ervâh ki tuhfe-yi Hüdầdır / Hâk-1 reh-i şâh-1 enbiyâdır." nât-1 şerîfindeki asıl gaye, "ervâh, hâk-i reh-i şâh-1 enbiyâdır" demekten ibaret olduğu halde, sıfat tamlaması olarak getirilen "ki tuhfe-i Hüdâ’dır" terkibi, haşv-1 melîhtir. Haşv-1 mutavassıt ise; söze güzellik vermediği gibi, çirkinlik de vermeyen haşv çeşididir: SahâifülAhbâr'da geçen "Endülüs'te olan Mülk-i Emeviyye on yedi nefer (kimse) olup, nesebleri kenarda tahrîr olunduğu veche üzeredir." ifadesinde geçen kimse sözcüğü, cümleye fazlalık katmıştır (Muallim Naci 1984: 27-38).

\section{Tanzimat Döneminde Bilgi ve Bilginin Yayılması}

Tanzimat dönemi çeşitli yönleriyle, Batı medeniyetini kabul ediş demektir. Tanzimat Fermanı, yeni bir medeniyet çevresine girmenin, kaçınılmaz olduğunun resmîleşmesidir. 1839 yılında Tanzimat Fermanı'nın ilanıyla, Batılılaşma bir devlet programı haline gelir ve tüm kurumlar yenilenmeye başlar (Enginün 2010: 23). Biz, burada Batı'dan gelen ve bizde var olan 
bilginin geniş kitlelere yayılması hususunda neler yapıldığına dair çok kısa bilgi vereceğiz. Onsekizinci yüzyılın ortalarında başlayan ve bütün ondokuzuncu yüzyılda genişleyerek devam eden, Osmanlının bilgi ve tekniğe açılma gerekliliği, Tanzimat yazarlarının da rağbet ettiği bir husustur. Batı'daki Rönesans hareketlerine, onu takip eden gelişmelere ve Aydınlanma dönemine ilgisiz kalan Osmanlı, ancak askerlik alanında ve toprak kayıpları karşısında uyanarak yeni bilgi ufuklarına açılma gereğini hisseder. İbrahim Müteferrika, kendi matbaasında basılan ilk kitaplara yazdığı mukaddimelerde ve koyduğu bazı notlarda birtakım Batılı ilim adamlarının adlarını sayar. Daha da önemlisi bu kitapların bir kısmının coğrafyaya ve Amerika gibi Osmanlı'nın o zamana kadar pek ilgisini çekmemiş olan ülkelere açılmasıdır. On sekizinci yüzyılın sonuna doğru mühendishanelerin açılmasıyla (17761795) özellikle matematik ve pozitif ilimlerde dönemine göre önemli sayılacak hamleler olmuştur. Bu bağlamda, akademik bir çevrenin henüz oluşmadığı on dokuzuncu yüzyılın başlarında müspet bilgiler alanlarında pek çok telif ve tercüme eser bulunmaktadır (Okay 2007: 61-82).

Tanzimat dönemi edebiyatının başlangıcı olarak kabul edilen 1839 yılı yaklaşırken ve on dokuzuncu yüzyıl boyunca, Batı kaynaklı modern bilgilerin, pozitif ilim verilerinin yayılması, devletin desteğiyle daha programlı bir şekilde gerçekleşir. Devlet halkın bilgi ve eğitim seviyesini yükseltmek için çeşitli tedbirler alır. Bu girişimlerden biri de okullaşmaya önem verilmesidir. Deniz (1773) ve Kara (1795) Mühendishaneleri'nin açılması, orduya hekim yetiştirmeyi amaçlayan Tibhâne-i Âmire (1827) ve Mekteb-i Ulûm-1 Harbiye (1834), Yeşilköy'de kurulan Ziraat Mektebi (1847), Mekteb-i Tibbiye-i Adliye-i Şâhane (1839), Mekteb-i Tibbiye-i Mülkiye-i Şâhane (1867), Kandilli Rasathanesi (1867), Gülhane Tababet-i Askeriye Tatbikat Mektebi (1898), Mekteb-i Harbiye (1849)'nin yanı sıra bu okullar için kaleme alınan ders kitapları, Batı’ya uyum gösterme çabalarındandır. (Dölen 1985: 155)

1863 'te öğretime açılan birinci Dârü'l-fünûn'da ilk dersi fizik ve elektrik üzerine veren Derviş Paşa olmuştur. 19. yy.'da Avrupa üniversitelerine öykünen Dârül-fünûn kurma girişimleri üç kere kesintiye uğrasa da ilk süreli üniversite, 1900 tarihinde açılmıştır. (Dölen 1985: 155-179).

Dârülfünûn açılmadan önce, ona hazırlık olmak ve eğitimde kullanılmak üzere eser yayımlamakla görevlendirilen Encümen-i Daniş̧ in (1851), Batı'daki benzerleri gibi bir ilimler akademisine dönüştürülmesi düşünülmüştür. 
Mecmua-i Fünûn gibi ilmî bir dergi yayımlayan Cemiyet-i İlmiyye-i Osmaniyye (1863) ve başlangıçta halka açık konferanslar veren Dârülfünûn (1863) gibi kuruluşlar, bilgilerin ve öğrenimin kurumlaşması için küçümsenmeyecek adımlardır. Bu kurumlarda ilmî ve metodik bilginin sınırları giderek genişlerken, aydınlar arasında ansiklopedik malumat edinme ve bu malumatı yayma özentisi başlar. İlmî ve meslekî dergilerin dişında edebiyat dergilerinin de sayfaları, Batı'dan gelen bilgileri okuyuculara nakletmeye başlar. Gazeteler de bu harekete katılır. Özellikle, siyasî konularda gizli ve açık bir sansürün uygulandığı 1880 yılından sonra, edebiyatla beraber ansiklopedik bilgi veren dergilerin sayısında da olağanüstü bir artış dikkati çeker. Bu edebî dergilerden birçoğu Hazine-i Fünûn, Servet-i Fünûn, Hazine-i Evrak, Maarif, Malumat, Malumat-ı Mütenevvia, Mektep, vb. ansiklopedik bilgilerin deposu anlamını çağrıştıracak adlar taşımaktadır. Bu gibi isimler, dergilerin edebî, fennî, coğrafî, tarihî, tıbbî, felsefî konuları ihtiva ettiğini haber verir (Okay 2007: 61-82).

Tanzimat dönemi dergilerindeki konular, hayret verici çeşitliktedir. Bu dergiler, yeryüzünde keşfedilen yeni topraklar, şema ve fotoğraflarıyla yeni icat edilmiş âlet, araç ve makineler, tedavi usulleri, tabiat güçlerinden, madenlerden, hayvanlardan yararlanma yolları gibi çoğu ilmî olmaktan ziyade pratik hayata getireceği faydalarla ölçülebilecek bir yığın bilgiyle doludur. Bu, bize aynı zamanda Tanzimat dönemi okuyucusunun Batı'daki gelişmelere karşı ilgisinin ne derecelere vardığını da gösterir. Seyahatnameler ve ansiklopedilerdeki bilgilere, başta Ahmet Midhat Efendi (1844-1912) olmak üzere Tanzimat edebiyatçıları ilgisiz kalmaz. Bu özelliğiyle şöhret bulan Ahmet Midhat Efendi, bilgiyi yazılarında ve küçük cep kitaplarında okuyucusuna aktarmakla kalmaz, "romanlarnnda" da kullanır. Diğer yandan, şiir gibi edebî özelliği daha baskın olan türlerde bile ansiklopedik bilgi kırıntıları yer alır. Dîvân edebiyatını ve bu edebiyatın eski mazmunlarını küçümseyen Tanzimat şâirleri, çağlarının fizik, astronomi, jeoloji, gibi fennî bahisleriyle ilgili yani bir çeşit yeni mazmunlarla örülü şiirler yazarlar. Şinasi, şiirlerinde Mustafa Reşit Paşa’nın adaletinin derecesini Newton'un hesaplayamayacağını söyler: "Ziyâ-yı akl ile tefrîk-i hüsn ü kubh olunur / Ki bûr-1 mihrdir evlâmı eyleyen teşhir." Namık Kemal, Ziya Paşa ile olan dostluğunu ve kavgasını anlatırken teşbih olarak yıldırımın pozitif-negatif güçlerinden bahseder: "Hem muvafık hem muhalifti Ziya ile Kemal / Şule-i berkıyede mevcut iki kuvvet gibi." Sadullah Paşa ise ilim ve tekniğin eriştiği yücelikleri tasvir ettiği On dokuzuncu Asır 
manzumesiyle, benzerleri arasında şiir estetiğine en çok yaklaşan şâirdir. Münif Paşa’nın mektebin ve eğitimin önemini belirtmek için kaleme aldığı Terkipbent, benzer fikirleri yansitan daha didaktik bir manzumedir (Okay 2007: 65).

Ahmet Midhat Efendi'nin eserlerinde “bilgi”nin önemli bir motif olması tesadüfî değildir. Tanzimat devrinin genel temayülü halkın bilgi seviyesinin yükseltilmesi doğrultusundadır. Eğitim ve öğretim meselesini hayatının ve eserlerinin temel düsturu haline getiren ve Hâce-i Evvel adıyla anılan yazar, bu yolla halka hizmeti amaçlar (Uğurcan 2006: 289-308). Ahmet Metin ve Şirzad romanında eğitim, tarih, coğrafya, filoloji, din, felsefe, mitoloji, arkeoloji, nümizmatik, astronomi, sanat tarihi, antropoloji, psikoloji, sosyoloji, etimoloji, mimari, fen, botanik, matematik, inşaat, gemicilik, ekonomi, mühendislik ve bilim tarihi hakkında ansiklopedik bilgiler vermesi, onun bu yönünü açıkça ortaya koyar.

Ahmet Midhat Efendi'nin pek çok mesele hakkında yazı yazması ve romanlarında bu konulara ayrıntılı bir biçimde değinmesi, araştırmacılar arasında bir eleştiri konusu olmuştur. Findley, Ahmet Midhat Efendi'nin yazarlığını İngilizce'deki eski bir sözle açıklar: "Jack of all trades, master of none." yani "Her sanatta çırak olan, hiçbirinde usta değildir." Findley’e göre; Ahmet Midhat Efendi, her sanatta çırak olmak sıfatıyla yetinmediğ $i$ halde, bununla meşhurdur. O, her şeyi yazmaya kalkışan, her şeyi bilir baba yazar tavrı takınan, yani kendi anlayışı ve davranışında hüküm sahibi olan bir yazardır. Buna rağmen, yazarın Avrupa'da Bir Cevelan kitabı sadece bir yığın genellemelerden ibaret değildir. Genellemeler arasında bir “örüntü” bulunmaktadır. Avrupa'da Bir Cevelan adlı eserin içinde son zamanlarda rağbette olan araştırma alanlarıyla ilgili bilgiler vardır: Seyahat, şarkiyat kongresi, dünya sergisi ile birlikte Avrupa terakkiyatının değerlendirilmesi, kadın konusu, kadın-erkek ilişkileri, kültürler arası mukayeseler bulunmaktadır. Ahmet Midhat Efendi'nin her şeye biraz değinen kitabı, bu özelliğiyle geniş bir okuyucu kitlesine hitap eder (Findley 1999: 1).

Tanzimat dönemi yazarlarından Namık Kemal, "Maarif" adlı makalesinde Avrupalılara dair tespitlerini, memlekette okulların ve okuma yazma bilenlerin sayısının arttırılması gibi ülkedeki cehaletin önlenmesiyle ilgili önerilerini açıkça beyan eder. Namık Kemal'in eserlerinin çoğu, özellikle hürriyete ve hürriyet yolunda mücadeleye dayanan fikrî temelli eserler olup, Ahmet Midhat Efendi'nin eserlerinden bu yönleriyle ayrılır. İstibdat döneminin 
okuma ve sanata ayrılan saatleri, Ahmet Midhat Efendi'nin eserlerine ayrılmışıı. O, bir yönüyle halkı kitap okumaya alıştırır. Ayrıca, Tanpınar edebiyat tarihinde yazarın eserlerinin halk nezdindeki dinlendirici fonksiyonu üzerinde durur (Tanpınar 2003: 459-460). Orta halli insandaki kitaba kaçış ve kitaba sığınma temayülü memlekete çok şey kazandırır. Halk romancısı diyebileceğimiz Ahmet Midhat Efendi'nin eserleri, entelektüel ve uzmanlık gerektiren bilginin halk ile buluşması ve halkın hizmetine sunulması demektir.

Ekonomi Politik (1874), Menfâ (1876), Üss-i İnkılâb (1877-1878), Kâinat (1871-1881), Mufassal (1885-1887), Müdâfaa (1883-1885), Şopenhavr'in Hikmet-i Cedîdesi (1887), Beşir Fuad (1887), Hallül-ukad (1889), Ahbâr-ı Âsâra Tảmîm-i Enzâr (1890), Avrupa'da Bir Cevelan (1890), İstibşâr (1892), Beşâir (1894), Nizầ-ı İlm ü Dîn (Okay 1989: 100-103) adlı bilim eserleri olan Ahmet Midhat Efendi, daha yaygın bilgiyi de roman ve hikâyeleri içinde verir. Edebiyattaki bilgiyi sanat ve felsefe bilgisi adı altında tasnif edebiliriz. Edebiyattaki bilginin kişisel bir şekilde işlenmesi, söz konusudur (Uygur 1977: 63-87). Bilim kitabı, uzmanlar okusun diye yazılır, edebiyat ise, herkese seslenir; fakat herkese açı bir dilin bilgi bakımından güçsüz olduğunu söylemek, önyargıya kurban gitmektir. Edebiyat dilinin, gerçeği de düşseli de anlatmak için çok uygun bir dili vardır. Shakespeare'in, Dostoyevski'nin ve Camus gibi büyük şahsiyetlerin eserlerine baktığımızda, her soylu yapıtın, bir doğrular barınağı olduğunu anlarız. Homeros'un Odysseia’sı dizi dizi kuşaklara bilgiler sağlamış bir üniversitedir (Uygur 1977: 68-86). Edebiyat yazarı, coğrafya, fizik, gökbilgisi, sosyoloji, psikoloji, tarih, arkeoloji ve felsefe gibi erişebildiği her kaynağa uzanır. Bu sebeple, bilimsel bilgilere yer veren edebî eserlerin hepsi, elden düşmecilikle suçlanamaz; çünkü edebiyatın, geniş bir kaplama alanı vardır: Haber yazıları, uzay öyküleri, (deneysel romanlardan başka) lirik şiirler, taşlamalar, düşsel anlatılar, denemeler... Edebiyatlaştırılmış bilgileri, ilgi ve hayranlık uyandırsın diye beceriksizce kullanan yazarlar vardır; fakat becerikli yazarların işlediği ve derlenebilen bilgiler, edebiyat ürünlerinin yüzkarası değil ak yüzüdür (Uygur 1977: 68-86). Rönesans ve Neo-klasik çağ düşünürlerinden zamanımıza gelinceye dek, ortaya konulan fikirlerden hareketle, sanatı tek başına bağımsız bir değer olarak sayamayız. Sanatın değeri, bilgisel olmasından ve ahlâk, politika, insan tabiatı gibi konularda okurlara faydalar sağlamasından ileri gelir. Sanat, bu gibi yüksek amaçlara hizmet ettiği için özel bir değer taşır. 


\section{Ahmet Metin ve Şirzad Romanında İstitrâd Değerlendirmesi}

Ahmet Metin ve Şirzad romanı ihtiva ettiği bilgilerin çokluğu ve çeşitliliği bakımından Ahmet Midhat Efendi' nin en kapsamlı eseridir. Bu bilgiler 19. yüzyılda yaşamış bir Osmanlı aydınının sahip olması gereken ve okuyucularına eseri vasıtasıyla öğrettiği temel bilgilerdir. Ahmet Midhat Efendi'nin bu hacimli romanında "bilgi", önemli bir motif hâlini almıştır. Ahmet Metin ve Şirzad romanında eğitim, tarih, coğrafya, filoloji, din, felsefe, mitoloji, arkeoloji, nümizmatik, astronomi, sanat tarihi, antropoloji, psikoloji, sosyoloji, etimoloji, mimari, fen, botanik, matematik, inşaat, gemicilik, ekonomi, mühendislik ve bilim tarihi hakkında ansiklopedik bilgiler vermesi, onun bu yönünü açıkça ortaya koyar.

Ahmet Midhat Efendi, eğitim ve öğretimi roman sanatının temeli hâline getirmiş bir yazardır. Romanda olay akışını birden keserek, o anda geçen bir durum, bir mesele, bir nesne hakkında bilgi verir, sonra tekrar esas konusuna döner. Ahmet Metin ve Şirzad roman1, Ahmet Midhat Efendi'nin istitradı en fazla kullandığı eserdir. Bu eserdeki istitradlar, 1. Müsbet ve insanî bilimlere dair bilgiler, 2. Denizcilik-gemicilik bilgileri, 3. Gidilen görülen yerlere, seyyahı bekleyen durumlara dair bilgiler, 4. Türk-Osmanlı ve İslâm medeniyetinin değerlerine dair bilgiler, 5 . Avrupa medeniyetine dair bilgiler, 6. Öğretim-eğitim meselelerine dair bilgiler olarak altı maddede toplanabilir. Abmet Metin ve Şirzad, yazarın ilk eserini yayınladığı 1870'den bu eseri yayınladığı 1891 tarihine kadar, bilgide ulaştığı son noktayı göstermesi bakımından önemli bir eserdir. Bu metindeki istitradlar, Ahmet Midhat Efendi'nin 1890'larda bir Osmanlı aydınının neler bilmesi gerektiğine dair görüşlerini de açıklamaktadır.

Abmet Metin ve Şirzad yahut Roman İçinde Roman kitabı, adından anlaşılacağı üzere iç içe iki hikâyeden ibarettir. Romanın başkahramanı Ahmet Metin'in yolculuğunun hikâyesi, Ahmet Metin'in okuduğu tarihî romanın kahramanı Şirzad'ın hikâyesi. Roman, bu hikâyenin izini sürmek için yola çıkan Ahmet Metin'in yolculuk seyri olduğu gibi roman kahramanı Şirzad'ın da yolculuk seyrini işler. Bu yüzden yazar romanına bu başlığı vermiştir.

Ahmet Metin Bosnalı çok zengin bir mültezimin oğludur. Babası Ahmet Metin'in öğrenim ve eğitimine çok dikkat eder, onu Mekteb-i Sultani’ye gönderir. Adından da anlaşıldığı gibi sağlam karakterli bir genç olan Ahmet 
Metin, aşırılıklardan kaçan, daima orta yolu tercih eden biridir. Babasından kalan mirası tüketmek yerine faydalı yollarda kullanmak ister. Çok bilgili ve kültürlü olmasının yanı sıra, başta denizcilik olmak üzere her türlü spora ilgisi vardır. Yüksekkaldırım'da bir sahaftan aldığı İtalyanca Cavaliero Turco romanı çok dikatini çeker. Roman, XIII. yüzyılda yaşayan ve Alanya Selçuklu Beyinin oğlu olan Selçuklu asilzadesi Şirzad'ın Akdeniz'deki maceralarını anlatmaktadır: Denizci Şirzad Sicilya Arapları ile bir arada iken İtalyanlara esir düşer. Bindirildiği gemide Roza isimli İtalyan kızına âşık olur. Fırtınada Şirzad ve Roza denize düşer ve issız bir adada zorlu hayat mücadelesi verir. Birbirine âşık olan gençleri, ıssız adadan Aydınoğlu Beyliği'ne ait bir gemi kurtarır. Roza Şirzad'ın şahsında hayran olduğu İslâm dinini kabul eder. İki genç Şirzad'ın ailesinin bulunduğu Alanyảya dönerler.

Ahmet Metin, bu romandan o kadar etkilenir ki Cavaliero Turco romanında Şirzad'ın gittiği her yeri görmek ister. Maksadı; sırf bir roman kahramanının izini sürmek değil, İstanbul'dan Sicilya dolaylarına kadar Türk, Müslüman ve Osmanlı'nın bütün tarihî izlerini görmektir. Görüp dolaştığı yerlerdeki başka medeniyetler de onun ilgi alanına girecektir. Ahmet Metin bu uğurda Meliketü'l-Bahr isimli bir gemi yaptırır. Geminin planını kendisi çizmiş, yapımına çok sıkı nezaret etmiş, gemicilerin seçimi ve yolculuk tedarikleriyle çok sıkı ilgilenmiştir. İstanbul, Kapıdağı Yarımadası, Çanakkale, Sakız yoluyla Pire'ye gelir. Orada Neofari isimli Moldovyalı genç ve güzel bir kadınla karşılaşır. Ahmet Metin gibi, babasından büyük bir servet kalan Neofari, ondan farklı olarak, memleketine çok yabancı kalacak bir eğitim ve öğretim görür. Genç ve havai Neofari kendisinden yaşça çok büyük olan zengin Akilio ile evlenir. Ondan Roza isimli bir kızı olur. Ancak Akilio'nun aşkı ve kızının varlığı, Neofari'ye yetmez. Çoğunlukla Pariste bulunan ve birçok âşığı olan Neofari, evlilik dışı en uzun ilişkisini kendisi gibi genç ve havai olan Nikolso ile yürütür. Neofari İngiliz seyyah Madam Brassey’ in devriâlem seyahatini anlattığı kitabından çok etkilenerek uzun bir deniz seyahati yapmak ve yaşadıklarını yazmak ister. Valesko teknesini kiralayarak Nikolso'ya eşi süsü vererek yola çıar. Pire'de Ahmet Metin ile bu ikili dost olurlar. Ahmet Metin’in yolculuğu kültürlü bir kadın olan Neofari'nin çok dikkatini çeker. Valesko teknesiyle o da geziye katılmak ister. Ancak teknenin yanması sonucu, Neofari ile Nikolso, Ahmet Metin'in gemisine sığınırlar ve Ahmet Metin'e yolculuğunda eşlik ederler. Yolculuk esnasında tekneyi yakanın, mücevherleri çalanın 
Nikolso olduğu anlaşılır. Nikolso'nun aradan çekilmesinden sonra, Neofari ile Ahmet Metin, Şirzad romanının izini sürme işine birlikte devam ederler. Yolculuk esnasında, Neofari Ahmet Metin'e âşık olur, Ahmet Metin ile hizmetçisi Vasiliki arasında bir ilişkiden şüphelenir. Gemi hizmetçilerinden biriyle onu öldürme planı yapar. Konuştuklarını duyan İtalyan kılavuzun onları ele vereceğinden korkarak onu denize atarlar. Olup bitenden ne Ahmet Metin'in ne de Vasiliki'nin haberi vardır. Ahmet Metin, her yerin coğrafyası, tarihi, yaşayan meşhur kişileri hakkında bilgi verir, hikâyeler anlatır. Şirzad'ın yaşadığı yerlere geldikçe, onun maceralarını bir roman gibi nakleder. Böylece Ahmet Metin ve Neofari Şirzad'ın romanını yaşayarak, görerek anlarlar. Gerek Şirzad'ın hikâyesi, gerek geçtikleri yerlerde başka medeniyetlere ait mitolojik ve tarihî hikâyelerle; Ahmet Metin iyi, güzel ve doğrunun ne demek olduğunu Neofari'ye hissettirmiş olur. Aynı zamanda bu hikâyelerle kötü, çirkin ve yanlışın sonuçta insanların başına hangi işleri getirdiğini de sezdirir. Böylece Neofari'ye bir ayna tutmuş olur. Hayatının muhasebesini yeniden yapan Neofari, hatalarının farkına varır. Eşi ve kızına geri dönmeye karar verir. Gezisine dair yazdıklarını bir Romen gazetesinde tefrika etme yolunda çalışmaya başlar.

Neofari’ nin bütün yolculuk boyunca Ahmet Metin'den kıskandığı Vasiliki ise geminin hesap memuru Süreyyàyı sevmekte ve onun tarafından sevilmektedir. Ahmet Metin kendi yetiştirdiği Vasiliki'ye metresi olmasını teklif eder. Daha sonra onunla evlenebileceğini de belirtir. Ancak Vasiliki Süreyya ile birbirlerini sevdiklerini söyleyince teklifini geri alır. İkisinin evlenmesi için maddi manevi destek olur.

Neofari'nin hayatı yoluna girmiş, seyahat yazıları yayınlanmaya başlamıştır. Ancak parkta yaptığ 1 bir gezintide nehire düşer ve boğularak ölür. Böylece, İtalyan kılavuzu öldürerek yaptığı fenalık, kendisine dönmüş olur. Neofari’nin sonunu Ahmet Midhat Efendi "Ceza amel cinsindendir. Her kim zerre mikdarda hayır yapar ise onu görür ve her kim zerre mikdarda şer yapar ise onu görür (Ahmet Midhat Efendi 1892: 730)" sözüyle açıklar. Bu söz Ahmet Metin ve Şirzad yahut Roman İçinde Roman kitabının son sözleridir.

Ahmet Metin ve Şirzad, Ahmet Midhat Efendi'nin romanları içinde istitrâdların en fazla yer aldığı romandır. Ahmet Hamdi Tanpınar, XIX. Asır Türk Edebiyatı Tarihi'nde, Ahmet Midhat Efendi'nin romanlarında 
geçen istitrâdları, yazarın romancılığının zayıf yönü olarak değerlendirir. Tanpınar'a göre, "Vaka birbiri peşinden gelen anekdotların, faydalı bilgilerin arasından güclükle kendisine yol açar" (Tanpınar 2003: 462). Orhan Okay ise, Batı Medeniyeti Karşısında Ahmet Midhat Efendi adlı çalışmasında, istitrâd meselesini edebî şahsiyetler, devir ve şartlar içinde tespit eder (2008: 471-472). Buna göre Okay, Ahmet Midhat Efendi'nin Mustafa Refik' in Musikinin Tesiri isimli tercümesine yazdığı takrizdeki, "Oğlum! Yalnız bir şeyi öğrenmeli, fakat mükemmel olarak! Yahut her şeyi öğrenmeli, bittabi nâkıs olarak! Osmanlılığımızın bügünkü hâline nispetle şu iki şıktan bence ikincisi müreccahtır. Ben sana onu tavsiye ederim. Fakat bundan sonra birincisi müreccah olacaktır. Sen de evlâdına onu tavsiye eyle!" öğütlerini göz önünde bulundurarak, onu kendi devrinin ve istikbâlin şartlarını iyi tanıyan bir aydın olarak değerlendirir (2008: 471-472). Yazarın kendi devrinde her şeyi sathî de olsa bilmek ve anlamak gereklidir. Ahmet Midhat Efendi, kendi devrinde bu millî hizmeti görmüş bir yazardır. Kendisinden sonraki dönemlerde ise ihtisaslaşmanın önem kazanacağının farkındadır. Yazarın romanlarında istitrâd olarak verdiği bilgileri, bu çerçevede düşünmek gerekir. Ahmet Midhat Efendi, Batı medeniyeti dairesine girdiğimiz bir devirde, Batı’nın maddî ve manevî değerlerini bilmek ve tanımak gerektiği inancındadır. Bu bakımdan "Ahmet Midhat Efendi'nin Ahmet Metin ve Şirzad Romanında İstitrâd Değerlendirmesi" başlıklı çalışmamızda istitrâdların Ahmet Midhat Efendi'nin şahsiyetini şekillendiren önemli bir unsur olduğunu tespit ettik. Bu tespitler, XIX. yy.'da yaşamış bir Osmanlı aydının neler bilmesi gerektiği sorusunu da cevaplar niteliktedir.

İstitrâdlar başlığı altında değerlendirdiğimiz bilgiler, içinde yaşadığı toplumu düşünen bir Osmanlı münevverinin sahip olduğu ve okurlarına öğretmek istediği bilgilerdir. Ahmet Midhat Efendi'nin maksadı, içinde yetiştiği Osmanlı toplumuna, hayata geçirilebilecek ve olumlu sonuçlar doğuracağına inandığ görüşü, insancıl yapısı, öğrenme-öğretme aşkı, pedagojik yönü ve bunları samimî bir ifade ile dile getirmesi etkili olur.

Ahmet Metin ve Şirzad romanında tasnif ettiğimiz bilgilerde çokluk ve çeşitlilik söz konusudur. Bu durum, yazarın edebî şahsiyetinden kaynaklandığı gibi bilginin önem kazandığı Tanzimat devrinin genel temâyülünden ileri gelir. Yazar, romandaki bilgileri romanın olay örgüsünden bağımsız olarak değil 
belli bir “örüntü” nün içinde yer verir. Bu bilgiler kısmen de olsa kurguyla bağlantılıdır. Örnek verecek olursak, Ahmet Metin ve Şirzad romanının ilk kısımlarında satın alınan ve özellikleri aktarılan fotoğraf makinesi romanın ortalarında Otranto'daki Santa Nikola Kilisesi'ni ve buradaki mozayikleri çekmek için kullanılır (Ahmet Midhat Efendi 1892: 383). Pozitivizm ve materyalizmin önem kazandığı dönem atmosferi, diğer Osmanlı aydınlarının yanı sıra Ahmet Midhat Efendi' yi de etkilemiştir: Ahmet Midhat'ın tarafsızlığa olan pozitivist inancı, bir fotoğrafın gerçeği yakaladığına ya da bir serginin dünyayı gösterdiğine inanan bir çağın güvenini ifade eder.

Romanda Meliketüll Bahr adlı bir gemi ile çıkılan Akdeniz seyahati, eserdeki bilgilerin işlenmesi bakımından, önemli bir zemin teşkil eder. Bu noktada, seyahat, eğlendirici bir etkinlik olmasının yanı sıra öğretici bir rol kazanır. Yol boyunca, Ahmet Metin, çoğunlukla seyahat arkadaşı olan Neofari'ye bilgiler verir. Neofari, Fransảda iyi bir tahsil görmüş, zeki bir ailenin kızıdır. Neofari'nin Ahmet Metin'e sorduğu sorular sayesinde konuşmalardaki bilgiler çeşitlilik kazanır. Bu da sohbette seviye meselesiyle ilgilidir. Yazarın romanda verdiği bilgiler, entelektüel bilginin halka ulaşması demektir. Bu sebeple, romanda açıklayıcı anlatım biçimi benimsenmiştir.

Bilime sonsuz güven duyan Ahmet Midhat Efendi, bunu Ahmet Metin ve Şirzad romanında sıklıkla dile getirir. Firdevsînnin "Tüvânâ bûd ân ki dânâ bûd" yani "Güçlü olan, bilgilidir" (Ahmet Midhat Efendi 1892: 12). sözünü benimseyen yazara göre; insanoğlu bilmediği şeylerden cehaleti sebebiyle korkar. Hâlbuki, doğayı kontrol altına almak, ancak ilim sayesinde mümkündür. Yazarın bu bakış tarzı mukayese ve tenkit fikrini de beraberinde getirir. Ondaki mukayese ve tenkit fikri, bir yönüyle olumlu gördüğü özellikleri kendi toplumuna kazandırma çabasından kaynaklanır: Örneğin, botanik bilimiyle meşgul olan Batılı bir araştırmacı, dünya denen beş kıtalık yerin her tarafını o kadar iyi tanır ki, bizler kendi hanemizin her köşesini bu kadar mükemmel tanımak davasında bulunamayız (Ahmet Midhat Efendi 1892: 331-332).

Yazarın, müspet bilimleri ve onların pratiğe döndürülmesine önem verişi, Osmanlının buna ihtiyacı içindir. Ancak, bu ihtiyacın daha derin ve temel bir sebebi vardır. Yazara göre; terakki, insanın yaratılışından gelir; çünkü insanoğlu, daima hayatta kalmak ve mutlu olmak ister. Medeniyet, işte bu yaratılış gereğinden hâsıl olmuştur. Fünûnda ve sanayide ilerleme fikrinin romanda 
işlenmesi ise, milletlerin ulaştığı tarihî başarılar ile ilişkilidir. Bir millet, cehaletle hiçbir şeye muvaffak olamaz (Ahmet Midhat Efendi 1892: 67).

Ahmet Midhat Efendi, sosyal bilimlere her zaman şüpheyle yaklaşır. Yazara göre; tarih, coğrafya, felsefe gibi sosyal bilimler, milletlerin menfaatlerine göre kasdî olarak değiştirilir. Buna karşılık, tarihî araştırmalarda, her zaman birincil kaynaklara müracaat edilmelidir. Uzman tarihçi, ilim ve irfan sahibi olmalıdır. Ayrıca, sadece bir vakadan hareket etmeyip, tarihin geneli üzerinde düşünmelidir. Ahmet Midhat Efendi'nin tarih biliminde en çok yer verdiği husus, doğru-yanlış meselesidir. Tarihî eserlerdeki yanlışlık ihtimallerini ortadan kaldırmak için Doğu ve Batı’ya ait kaynakları mukayeseli bir biçimde okur. Bilginin güç olduğuna inanan yazar, her firsatta, Türk-Osmanlı ve İslâm medeniyetinin değerlerini yüceltir. Ahmet Midhat Efendi, bunu, yüzeysel bir iltifat üslûbu ile değil, Doğu ve Batı dünyasına ait başvuru kaynaklarına dayandırdığı fikirler ve bilgiler ile dile getirir. Romanın başkahramanı Ahmet Metin, Avrupáda sadece Şirzad'ın değil tüm Türk-Osmanlı ve İslâm tarihinin izlerini arar. Manevî galibiyetin ve medenîleşmenin önemi üzerinde durur. Burada, Ahmet Midhat Efendi'nin tarihi bir bütün olarak görmesi önemlidir. Ahmet Midhat Efendi, coğrafyayı Türk tarih ve medeniyetini merkez alan karşılaştırmacı bir yaklaşımla işleyerek, Batı medeniyetinin, Doğu medeniyetinin hayrül-halefi oluşunu çok yönlü bir bakış açısıyla ispat eder.

Filoloji bahsinde yazar, filologların araştırmalarıyla milletlerin sanayialarının yanı sıra edebî, siyasî ve askerî eserlerinin gün ışığına çıkarılacağını belirterek, bu bilimin önemine değinir. Ulûmda ve sanayide hangi millet önde ise o milletin lisanını öğrenmek zarurîdir. Milletler, bu bakımdan diğer milletlerin dillerinden terimler almışlardır. Yazar, dillerarası kelime alışverişine değinirken bizzat kelime örnekleri vererek açıklamalarda bulunur. Tanzimat devrinde, Ahmet Vefik Paşa, Şemseddin Sami gibi şahsiyetlerin dil ve sözlük çalışmalarına, Ahmet Midhat Efendi de ilgisiz kalmaz.

Ahmet Midhat Efendi'nin eserlerindeki bilgi aktarımı, Ahmet Hamdi Tanpınar'ın eserlerindeki gibi üstü kapalı bir şekilde değil doğrudan ve kaynak gösterilerek yapılır. Ahmet Metin ve Şirzad romanında geçen bazı kaynak isimleri şunlardır: Ahmet Midhat Efendi' nin yazmış olduğu Kırk Anbar isimli mecmuanın "Tarih-i Osmaninin Kısm-1 Şairanesi" diye içinde yer alan birkaç makale, yazarın Hasan Mellah, Hüseyin Fellah, Demir Bey gibi romanların ve Avrupa'da Bir Cevelan, Sayyadane bir Cevelan adlı seyahatnameleri, ünlü 
İngiliz yazarı Madam Brassey'in devr-i alem seyahati, Hammer'in Osmanlı Tarihi, Cesar Cantu'nun Tarih-i Umumiye'si, Tâcüt-Tevarih, Message de Temps Gazetesi, Portolan Mecmuası, İdrisînin Nüshetüll-Müstâk fi İhtirâkı'l Âfâk adlı meşhur kitabı, Oxford'da ilm-i elsine-yi umumiye muallimi olan Mösyö Maks Müller' in dillerin oluşumu hakkındaki fikirleri, Schopenhauer'ın Felsefî Görüşleri, Jean Jacques Rousseau, Emile Zola'nın tabiî denilen romanları, Cervantes'in Don Kişot Romanı, Tolstoy'un eserleri, İbn-i Sina, Muhyiddin Arabî ve İbn-i Rüşd gibi şarkın yüzlerce ulemâsının ve Alexandre Dumas'ın eserleri, Daniel Defoue'nin Robinson Crusou adlı eseri, Safo'nun şiirleri, Fransız tarih yazarı Abu, Paul isimli İskenderiye'de tıp tahsili yapan bir tabibin eseri.

Ahmet Midhat Efendi için bilginin edebiyattaki yeri mühimdir. Yazar, Ahmet Metin ve Şirzad romanında çeşitli bilim dallarına dair bilgiler verdiğini, bizzat kendisi belirtmiştir. Tarih-edebiyat ilişkisi konusunda yazar, İslâm ve Osmanlı tarihlerinin roman ve roman sanatı için önemli bir zemin oluşturduğunu söyler. Edebiyat-mitoloji ilişkisi bağlamında ise, yazar mitolojinin geniş bir ilim olduğu düşüncesindedir. Bu mitolojik hikâyeler, milletlerin edebiyatlarına temel olmuştur (Ahmet Midhat Efendi 1892: 327).

İlâhiyat başlı̆̆ı altında işlenen istitrâdlar, din-mitoloji ilişkisi, Kur'ân-ı Kerim, Incil, Tevrat gibi kutsal kitaplar, İslâmiyet ve Hristiyanlık gibi dinlere dair bilgileri ihtiva eder. Bu gibi kısımlarda Ahmet Midhat Efendi, İslâm dininin üstün özelliklere sahip ve hayata dönük bir din olduğunu vurgular.

Romanda geçen iktisadî bilgi ve fikirler, memleketini seven bir Osmanlı münevverinin iktisadî fikirleriyle yakından ilgilidir. Ahmet Midhat Efendi için paranın iktisatlı harcanması, önemlidir. Ahmet Metin, millî sanayiye yardım etmek için teknesini kendi memleketinde yaptırır ve gemi çalışanlarının Türk olmasında taassup gösterir. Yazar, romanında Avrupa sigorta kumpanyaları hakkında malumat vererek okurlarını, onun getirdiği faydalardan haberdar eder. Tüm bu ikazlar, ticaret-i Osmaniye’yi geliştirmek içindir.

Romanda, gemicilikle ilgili teknik konuların ağırlıklı olarak işlenmesi, Ahmet Midhat Efendi'nin, terakkiyat fikrinden ileri gelir. 19. yy. ile artan ilmî çalışmalar, sanayileşme, mekanikleşme gibi gelişmeler, teknolojiyi yakından takip eden ve bilginin güç olduğuna inanan yazar için önemli bir mesele hâlini alır. Yazar, aynı zamanda 20. yüzyılda terakkinin en önemli problemlerinden 
olan çevrecilik problemlerinin farkındadır. Yazarın verdiği fikir, terakkinin getirdiği zararlara şimdiden çare bulunmasıdır.

Gemideki araç-gereçler, pratik olanın seçimine özen gösterilerek tamamlanır. "Tamamlamak" kelimesi, Ahmet Midhat Efendi'deki, tedbirlilik, tamamlayıcılık ve uzak görüşlülük fikri ile ilgilidir. Yazarın, bilgi vermedeki eksikliğe tahammülü yoktur. Yazar, dikkat etmeden kullandığımız taşıtların en ufak parçasından son hâline kadar nasıl zorluklarla yapıldığını göstererek üretimin ne demek olduğuna dikkatimizi çeker.

Ahmet Midhat Efendi'nin amacı, İslâm ve Türk tarihinin nerelere kadar genişletilebileceğini ve Avrupa ile ilişkilerin hangi dereceye getirilmiş olduğunu ortaya çıkarmaktır. Ahmet Midhat Efendi, bu konuda tarihlerimizin eksik kaldığını düşünerek, okurlarını aydınlatmak ister. Yazar, Osmanlıların dünyada hiçbir milletin tarihi ile kıyas kabul edilmeyecek şanlı bir tarihi olduğunu Doğu ve Batı kaynaklarına başvurarak ispat eder. Bu ispat ediş, "Biz, nasıl bir milletiz?" sorusunun cevabıdır: "Bizim Osmanlılığımızda iki şan vardır ki bunların yalnız birisi bile bizim için teşerrüfe kafi iken Hak Teâlâ Hazretleri bizi onların ikisiyle birden mübeccel eylemiştir. Bunların da birisi Müslümanlık diğeri Türklük! Bu iki şeyin ikisinin de tarihleri cihanda hiçbir milletin hiçbir halkın tarihine kıyas kabul edemeyecek derecelerde kahramanâne ve şairânedir. O sûret-i kahramanâne ve şairânenin derecesine ise bizim vukufumuzdan ziyade yine Avrupalıların vukufu şamildir" (Ahmet Midhat Efendi 1892: 38-39). Avrupalıların, kendilerine ait olmayan bir milletin tarihi ile uğraşmaları, Ahmet Midhat Efendi'nin hayran olduğu bir husustur. Avrupalıların bilgisinin bu denli kapsayıcı oluşunun sebebi, Avrupalıların yaptığı tarihi araştırmalardır. Zira, bu tarihi araştırmalar onlara sadece sekiz on asırlık Türk tarihinin, on iki on üç asırlık Müslüman tarihinin, hatta yirmi beş otuz asırlık Roma, Yunan, Mısrî, Asurî, İran vesaire tarihlerinin bile ince ve derin meselelerini çözdürmüştür (Ahmet Midhat Efendi 1892: 38-39).

Ahmet Midhat Efendi, romanında Avrupa Medeniyeti ile ilgili çeşitli bilgiler verir. Bu medeniyete, Doğu'dan çok şey geçmiştir. Makaronya, kuskus, şehriye, kadayıf yiyecekler, Arapların icadı iken, bunlar daha sonra Batı dünyasının yiyecekleri olmuştur. 13. yüzyılda Sicilya Arapları'nın üzerinde yemek yediği seccadeleri, bugün Avrupalılar duvarlarına dekor olarak asarlar (Ahmet Midhat Efendi 1892: 512). Güneş saati ve takvimler düzenleyen 
Arap gemicileri, Hint sahillerinde ve okyanuslarda henüz coğrafya âleminin bilmediği yeni yerler keşfetmişlerdir. Daha sonraları Avrupalılar, Araplar’ın "hayrülhalefi" olarak onlardan aldıkları ilimleri ilerletmişlerdir. Araplar, Avrupalılar için nasıl öğretici olmuşlarsa, Avrupalılar da bugün bizim için öğretici olmuşlardır (Ahmet Midhat Efendi 1892: 482). Batı medeniyetinin, Doğu medeniyetinin "hayrül-halefi” olduğu düşüncesi, Ahmet Metin ve Şirzad romanının dayandığı temel fikirdir.

Yazara göre 19. yüzyılda Avrupa'da yaşayan bir aile, saadetten yoksundur; çünkü eşler, sâdık değildirler. Aynı ev içinde yaşadıkları halde birbirinden ayrı olan karı-kocalar gibi Avrupa medeniyetinin pek çok tuhaf yanı bulunmaktadır. (Ahmed Midhat Efendi 1892: 194-195) Alafranga usûllerle yetiştirilen Neofari'nin mutsuzluğunun bir diğer sebebi ise, kocasına ihanet etmesidir. Neofari, çocuğu ve kocası ile yaşamaktansa, sevgilisi Nikolso ile seyahate çıkmayı tercih eder. Romanda işlenen bu parçalanmış aile, Avrupa medeniyetinin zayıf yönü olarak ele alınır. Avrupa medeniyetinin bir diğer zayıf yönü ise, 19. yy. Avrupa'sında sıkça görülen kıskançlıklar, düelloları ve intiharlardır: "Düello, intiharlar işte kendilerini kurtaramamış olmalarının asarıdır" (Ahmet Midhat Efendi 1892: 156). Neofari'nin sevgilisi Nikolso da romanın ilerleyen kısımlarında düelloda öldürülür (Ahmet Midhat Efendi 1892: 474).

\section{Sonuç}

Türk örf ve âdetleriyle Osmanlı kültürünü benimseyen Ahmet Midhat Efendi, bu kültürün unsurlarını batının ilim ve tekniği ile birleştirilmesini ister. Batılılaşma sürecinde millî şahsiyetin muhafaza edilmesi yazar için mühimdir. Yazarın, eğitim ve öğretimi, hayatının ve eserlerinin temel kuralı hâline getirmesini, Ahmet Metin ve Şirzad romanında da tespit etmek mümkündür. Eserde, bilgi sahibi olanın, bilmeyene öğretmesi söz konusudur. Romanın baş kahramanı Ahmet Metin, genellikle öğretici; diğer kahramanlar ise öğrenen konumundadır. Ahmet Metin, bilmediği bazı bilgileri ise George Gossar adlı arkadaşından öğrenir. Kitaplar, mecmualar, haritalar, bilgili arkadaşlar, bir mektep kabul ettiği seyahatler, Ahmet Metin’in bilgi kaynaklarıdır.

Ahmet Midhat Efendi'nin istitradlarla klasik bilgilendirme tarzı, zamanımızdaki Orhan Pamuk ve Oktay İhsan Anar gibi postmodern yazarların, bilgilendirme tarzından çok farklıdır. Faydacı zihniyete sahip Ahmet Midhat Efendi, açıkça okuru aydınlatırken bu yazarlar, bilgiyi daha 
karmaşı ve esrarengiz bir şekilde sunarlar. Ancak, bu yazarlar da eserlerinin arka planında büyük araştırmalar yaparlar. Hatta bu yazarlar, kitap, bölüm başlarında ve içlerinde kısa veya uzun iktibaslar yaparlar. Böylece, o metinler ile yazdıkları arasında lehim kurmaya çalışırlar ve bu yolla bilginin her çeşidini eserlerinde kullanmış olurlar. Bu da Ahmet Midhat Efendi tarzı bilgilendirmenin zamanımızda aldığı şekildir.

Ahmet Midhat Efendi'nin bu romandaki istitradlarındaki bilgileri Tanzimat' in temel ideolojileriyle birleştirmek de mümkündür. Ahmet Midhat Efendi, Tanzimat'ın genel ideolojileri olan Medeniyetçilik, İslâmcilık ve Osmanlıcılık ile 1890’larda bunlara eklediği Türkçülük ideolojilerinin bütün değer yargılarını, aynı zamanda bu ideolojilerin temel alanlarıyla ilgili bilgi dağarcı̆ğ ile besler. Romanın konusunun elverdiği ölçüde çok geniş bir bilgi dağarcığını romanın bütününe yayar. Bu bilgi, Ahmet Midhat Efendi' nin, 1890'lı yıllarda bilinçli Türk okuyucusunun sahip olmasını gerektiğini düşündüğü bilgidir. Sabri Esat Siyavuşgil, İstanbul Üniversitesi'ne Ahmet Midhat Efendi'nin heykelinin dikilmesini temenni ederken, edebiyatın bu bilgilendirme fonksiyonunu hatırlatmak istiyordu.

Ahmet Metin ve Şirzad romanının dayandığı temel fikir, Batı medeniyetinin Doğu medeniyetinin "hayrül-halefi" oluşudur. Batı, ait olduğu ilim ve teknik gibi maddi değerleri Doğu dünyasından öğrenip, bu bilgileri geliştirmiştir. Ahmet Midhat Efendi, 19. yüzyılda bir Osmanlı aydınının sahip olması gereken bilgileri okurlara öğretirken, okurlarına güven aşılamak ister. Doğu medeniyetinin manevi değerlerini muhafaza eden Türkler de gerekli eğitimöğrenimi görürlerse, medeniyet temsilcisi olarak kabul edilen Batılının yaptığı her şeyi yapabilir ve eski günlerdeki üstünlüklerine tekrar kavuşabilirler.

\section{Kaynaklar}

Ahmet Midhat Efendi (1892). Ahmet Metin ve Şirzad yahut roman içinde roman. İstanbul: Tercüman-1 Hakikat Matbaası.

Aristoteles (2006). Poetika. Çev. İsmail Tunalı. İstanbul: Remzi Kitabevi.

Asiltürk, Baki (2000). Osmanlı Seyyablarnnın Gözüyle Avrupa. İstanbul: Kaknüs Yay. Budak, Ali (1986). Şiir ve Bilgi. İstanbul: Boğaziçi Yay.

Devellioğlu, Ferit (1993). Osmanlıca-Türkçe Ansiklopedik Lûgat. Ankara: Aydın Kitabevi. 
Dölen, Emre (1985). “Tanzimat'tan Cumhuriyet'e Bilim”. Tanzimattan Cumburiyet'e Türkiye Ansiklopedisi. İstanbul: İletişim Yay. 155.

Durmuş, İsmail (1989). "İstitrat". İslâm Ansiklopedisi. C. 23. İstanbul: Türkiye Diyanet Vakfi Yay.

Enginün, İnci (2010). Yeni Türk Edebiyatı Tanzimat'tan Cumburiyet'e (1839-1923). İstanbul: Dergâh Yay.

Findley, Carter V. (1999). Ahmet Midhat Efendi Avrupa'da. Çev. Ayşen Anadol. İstanbul: Tarih Vakfi Yurt Yay.

Karpat, H. Kemal (2009). Osmanlıdan Günümüze Edebiyat ve Toplum. İstanbul: Timaş Yay.

Laçiner, Ömer (2011). Modern Türkiye’de Siyasî Düşünce. İstanbul: İletişim Yay.

Mengi, Mine (2008) "Evliya Çelebi Seyahatnamesi’nde Bir Üslûp Özelliği Olarak Türler Arasılık”. Çă̆ının Sıradışı Yazarı: Evliya Çelebi. Haz. Nuran Tezcan. İstanbul: Yapı Kredi Yay. 281-291.

Moran, Berna (2008). Türk Romanına Eleştirel Bir Bakış-1. İstanbul: İletişim Yay.

Muallim Naci (1984). Istılahat-ı Edebiyye. Haz. Alemdar Yalçın ve Abdülkadir Hayber. Kayseri: Akabe Yay.

Nutkî, Süleyman (2011). Kamusı Bahrî. Haz. Mustafa Putlar. İstanbul: Türkiye İş Bankası Yay.

Okay, Orhan (2008). Batı Medeniyeti Karşısında Ahmet Midhat Efendi. 4. bs. İstanbul: Dergâh Yay.

Okay, Orhan (2011). Sanat ve Edebiyat Yazıları. İstanbul: Dergâh Yay.

Okay, Orhan (2007). “Tanzimatçılar: Yenileşmenin Öncüleri (1860-1896)”. Türk Edebiyatı Tarihi. Haz. Talat S. Halman vd. C. 3. İstanbul: Kültür ve Turizm Bakanlığ 1 Yay.

Ortaylı, İlber (2009). Son İmparatorluk Osmanlı. İstanbul: Timaş Yay.

Öner, Necati (1984). "Bir Bilgi Türü Olarak Sanat”. Suut Kemal Yetkin’e Armağan. C. XX. Ankara: Hacettepe Üniversitesi Yay.

Parla, Jale (2006). “Rakım Efendi’den Nurullah Bey’e, Cemaatçi Oamanlılıktan Cemiyetçi Türk Milliyetçiliğine Ahmet Mithat'ın Romancılı̆̆ı”. Ahmet Mithat Üzerine Eleştirel Yazılar, Merhaba Ey Muharrir!. Haz. Nüket Esen ve Erol Köroğlu. İstanbul: Boğaziçi Üniversitesi Yay.

Tanpınar, Ahmet Hamdi (2003). 19uncu Asır Türk Edebiyatı Tarihi. İstanbul: Çağlayan Kitabevi.

Uğurcan, Sema (1995). “Ahmet Mithat Efendi'nin Romanlarında Tarih ve Medeniyet". Türk Dili Dergisi (Ahmet Midhat Efendi Özel Bölümü). Ankara: TDK Yay. 521-528.

Uygur, Nermi (1977). Edebiyat ve Bilgi. İstanbul: İstanbul Üniversitesi Edebiyat Fakültesi Basımevi.

Ülgen, Erol (1994). Ahmet Midhat Efendi'de Çalışma Fikri. İstanbul: Ahilik Araştırma ve Kültür Vakfı Yay. 


\title{
The İstitrad Evaluation in The Novel of Ahmet Metin and Şirzad of Ahmet Midhat Efendi*
}

\author{
Funda Çapan Özdemir ${ }^{* *}$
}

\begin{abstract}
Ahmet Mithat Efendi is a writer who made education and training the basis of the art of novel. Interrupting the course of events in the novel, he transforms to an immediate event, object or issue and starts to talk about them and later on he continues to write through the main flow of the novel. This "istitrad" technique was most widely used in his work Ahmet Metin and Şirzad. The six main types of the art of "istitrad" are: 1 . Knowledge on positivisms and humanity, 2. Knowledge on seamanship and shipping, 3. Places reached and seen, 4. Knowledge on values of Turkish- Ottoman and Islamic civilizations, 5. Knowledge on European civilization, 6. Issues related to education and training. Ahmet Metin and Şirzad has been an important work of him in that it reflects the highest point of knowledge Ahmet Mithat Efendi reached from the first work he published in 1870 to the publication of this work in 1891. The art of "istitrad" he used in this work explains what Ottoman intellectuals were to know in 1890s as well.
\end{abstract}

\section{Key Words}

Ahmet Midhat Efendi, intellectual, novel, istitrâd, information, learning, teaching.

\footnotetext{
Date of Arrival: 11 February 2014 - Date of Acceptance: 16 June 2014 You can refer to this article as follows: Çapan Özdemir, Funda (2019). “Ahmed Midhat Efendi'nin Ahmet Metin ve Şirzad Romanında İstitrâd Değerlendirmesi”. bilig - Türk Dünyast Sosyal Bilimler Dergisi 88: 205-226.

" Dr. Lecturer. Yozgat Bozok University, Faculty of Science and Letters, The Department of Turkish Language and Literature, The Department of New Turkish Literature Faculty Member - Ankara/Turkey ORCID ID: http://orcid.org/0000-0002-3950-4842 funda.capan.ozdemir@bozok.edu.tr
} 


\title{
Использование отступлений в романе Ахмеда Мидхата Эфенди «Ахмет Метин и Ширзад» Фунда Чапан Оздемир ${ }^{*}$
}

\begin{abstract}
Аннотация
Ахмед Мидхат Эфенди - писатель, который сделал образование и обучение основой искусства романа. Прерывая ход событий в романе, он сосредоточивается на определенном событии, предмете или проблеме и начинает рассказывать о них, а затем возвращается к основному повествованию. Более всего подобных отступлений встречается в романе Ахмеда Мидхата Эфенди «Ахмет Метин и Ширзад». В этом романе отступления можно разделить на шесть групп: 1. Сведения о человеке и естествознании, 2. Сведения о мореплавании и судоходстве, 3. Места, в которых он побывал, 4. Сведения о ценностях тюрко-османской и исламской цивилизаций, 5 Сведения о европейской цивилизации, 6. Вопросы, связанные с образованием и обучением. Роман «Ахмет Метин и Ширзад» является этапной работой, отражая тот уровень знаний, которого Ахмет Митхат Эфенди достиг с момента публикации своего первого произведения (1870 г.) ко времени создания данного романа в 1891 году. Искусно использованные им отступления отражают взгляды Ахмеда Мидхата Эфенди на то, что должны были знать османские интеллектуалы 1890 -х годов.
\end{abstract}

\section{Ключевые слова}

Ахмет Митхат Эфенди, интеллектуал, роман, отступление (иститрад), сведения, изучение-обучение

Поступило в редакцию: 11 февраль 2014 г. - Принято в номер: 16 июнь 2014 г. Ссылка на статью:

Çapan Özdemir, Funda (2019). “Ahmed Midhat Efendi'nin Ahmet Metin ve Şirzad Romanında İstitrâd Değerlendirmesi”. bilig - Türk Dünyası Sosyal Bilimler Dergisi 88: 205-226

** Д-р, преподаватель. Университет Бозок в Йозгате, Факультет искусств и наук, отделение турецкого языка и литературы - Бозок / Турция ORCID ID: http://orcid.org/0000-0002-3950-4842 funda.capan.ozdemir@bozok.edu.tr 